\title{
The Poverty Alleviation and Immigration Practice Model Effect Research in Liulin
}

\author{
Yumei Liu'1, Longyi Xue ${ }^{1}$, Yaolin Wang² \\ ${ }^{1}$ School of Geography Science, Shanxi Normal University, Linfen, China \\ ${ }^{2}$ School of Geography, Melbourne University, Melbourne, Australia \\ Email:923148470@qq.com
}

How to cite this paper: Liu, Y. M., Xue, L. Y., \& Wang, Y. L. (2016). The Poverty Alleviation and Immigration Practice Model Effect Research in Liulin. Chinese Studies, 5, 101-109.

http://dx.doi.org/10.4236/chnstd.2016.54012

Received: September 5, 2016

Accepted: November 6, 2016

Published: November 9, 2016

Copyright (c) 2016 by authors and

Scientific Research Publishing Inc.

This work is licensed under the Creative

Commons Attribution International

License (CC BY 4.0).

http://creativecommons.org/licenses/by/4.0/

\begin{abstract}
By the way of field investigation and statistical analysis, I have carried on investigation to Liulin, migrant village and I have learnt something about migration forms, mainly interaction patterns of villages and towns aggregation model. This article mainly analyzes the work and the necessity of immigration for poverty alleviation and the actual effect of the two modes in Lilulin. Moreover, I put forward some suggestions to model improvement and hope that I can do some useful things to poverty reduction in Liulin. At the same time, it can provide favorable help for building a harmonious society.
\end{abstract}

\section{Keywords}

Liulin, Immigration, Practice Patterns for Poverty Alleviation, Effect Analysis

\section{Introduction}

At present, domestic scholars for the study are mainly about the patterns of immigration practice focuses on the need because of the major infrastructure construction of the physical and the western impoverished mountainous area of developmental immigrants, but the unbalanced development in central and eastern coastal areas of poverty alleviation immigration practice model research is weak (Li Wangming \& Jin Dengyang, 2008). Liulin is located in the central region of our country, and the development of its economy is rapid, but the gap between rich and poor is big.

The immigrants of Liulin are mainly aimed at three target groups: remote and inaccessible mountain terrain extremely poor people, in mining subsidence area and people who live in road project construction area. According to the principle of combining government guidance with the wishes of the masses, they moved to the good places. The project of immigration is started in 2003. The immigration has involved each 
township as yet, which makes most of the poor by moving down the path of adequate food and clothing and become rich. In this paper, through on-the-spot visited Jin Jia Zhuang town Ma Wei Gou village, new village of Ge Lao Wan in Xue town, Chen Jia Wan town Guo Jia Shan village, the town after Hou Yuan Zhuang village on a total of four immigration village, we have carried on the statistical analysis, studied the Liulin immigration patterns and their effects, found the deficiencies and put forward suggestions. I hope that the new rural construction of Liulin and promoting poverty alleviation immigration can help them well.

\section{The Necessity of County Profiles and Their Poverty Alleviation}

Poverty alleviation and migration of Liulin is closely related to geographical environment. Next, I will make a brief description about it. It included general situation of the natural geography and human geography Liulin, and analysis of the necessity of county poverty alleviation immigrants.

\subsection{Natural Geography}

Liulin, located in the west of Lvliang mountains, along the eastern coast of the Yellow River. It is a temperate continental climate place, climate type seasonal drought is relatively serious, rainfall concentrated in the summer, the temperature in poor is big. There are three rivers and two Jin Guzhuang rivers, influenced by water cut effect, it makes the landform in the staggered hills gully aspect, hill, the tableland and gully terrace four types. It is rich in mineral resources. People have found 15 kinds of them, give priority to with coking coal, limonite, bauxite, limestone, etc. "Grahame is located in the famous east edge of Ordos coal-accumulating basin hinterland of the Hedong coalfield, the county coal storage area of 480 square kilometer, $37 \%$ of the total area of the county.

\subsection{Human Geography}

The migration patterns of Liulin is mainly restricted by terrain, resources and other natural conditions, but also closely related to human geography. Next, I want to mainly describe residential distribution characteristics and economic development of Liulin.

\subsubsection{Settlement Distribution Characteristics}

The total area of Liulin is 1288 square kilometer, its population is 291thousand. Throughout human history of the origin of the four great ancient civilizations are related to the river, originated in two rivers in ancient Babylon, ancient Egypt originated in the Nile valley, ancient India originated in the Indus and the Ganges River, while China originated from the Yellow River basin. Of course, residents distribution in Liulin is closely related to the river. Along the Sanchuan River flat, because the water is rich, the transportation is convenient, and it has the superior conditions of economic development, thus the densely populated. By land barren outlying mountainous area, water resources shortage, traffic inconvenience, poor economic development conditions, so the sparsely populated. The fourth national census found out, the county's 
population density of 190.65 people per square kilometer. Along the sanchuan river grahame, Mu village, the lijiawan, Xue village, township 5 more populous, $18.13 \%$ of the total area of area of county land, population account for $36.33 \%$ of the total population of the county. The GeTai and reputation township population density was still less than 100 people per square kilometer in 1990 (Li Jiulin, Li Ruzhi, \& Liu Tingkui, 1995).

\subsubsection{Economic Development}

The economic development of Liulin is good. This is a table about fiscal income of a few years (Source: Statistical Yearbook of Shanxi Province).

From Table 1, we can see the overall fiscal income of Liulin is rising. In 2008, because of the influence of the financial crisis, fiscal revenues have fallen. From 2009 year, the continued development of economy, the fiscal revenues continue to increase.

\subsection{The Necessity of Immigration for Poverty Alleviation}

Liulin is located in the famous east edge of Ordos coal-accumulating basin hinterland of the Hedong coalfield. It is very famous for coal resources. It makes economic of Liulin development is given priority to with coal type heavy industry industrial structure, Grahame relying on coal resources since the 21st century. But because of long-term coal mining to the living conditions of the residents in the mining area caused some negative effect. On the one hand, increased the ordinary residents with coal mine enterprise investor's income gap; On the other hand, it makes some residential areas appear subsidence due to coal mining. At the same time, because of coal mining enterprises to discharge waste water, waste gas, solid waste and caused serious pollution to the environment. This makes immigration of Liulin is imperative.

As the saying goes: "If we want to be rich, we must build roads first". From this sentence, we know we should regard the traffic as the primary factors from poverty and becoming rich. Due to the rugged terrain in impoverished mountainous area, traffic inconvenience restricted the local economy development. In 4 immigration villages, including Jin Jia Zhuang town Ma Wei Gou village and new village of Ge Lao Wan in xue town two old bay village, village former residents living in the top of the mountain, the mountain or hill, living scattered form, country road, village road is only suitable for pedestrian, is not conducive to the vehicle travel, residents, in turn, reduces the

Table 1. 2007-2012 Fiscal Revenue of Liulin County.

Unit of measurement: billion yuan.

\begin{tabular}{cc}
\hline Year & Fiscal Revenue \\
\hline 2007 & 43.4 \\
2008 & 35.2 \\
2009 & 44.7 \\
2010 & 51.8 \\
2011 & 72.2 \\
2012 & 86.35 \\
\hline
\end{tabular}


communication with the outside world, but also restrict the development of local economy. Village land on slopes, and the slope is greater than 30 degrees, more summer precipitation concentrated period of time, aggravated soil erosion, soil loss of organic composition, more barren soil, is not conducive to crop growth. In addition in recent years, due to the climate changing, greatly reduces the production of crops and make people live on land can't keep. Only through the way of migration, we can fundamentally improve traffic conditions, make to the impoverished mountainous area truly rich (Yang Guolin \& Luo Qiangqiang, 2009).

\section{The Practice Patterns and Liulin, Poverty Alleviation and Immigrants}

By looking through Liulin Government Websites report on immigration for poverty alleviation work, understand the 2008 year of poverty alleviation and development work summary report, migration forms of Liulin, mainly take the interaction between the mine of villages and towns aggregation model, combining the whole village promotion with of the new rural construction in the relocation. Governments built high standard saemaul undong immigrants, overfulfilled migration tasks, and make the most of the young labor transfer to companies, achieve the leap development from poverty to a well-off. In my field research in 4 immigrants village, Chen Jia Wan town Guo Jia Shan village and the town after Hou Yuan Zhuang village belongs to the village after the interactive mode; Jin Jia Zhuang town Ma Wei Gou village and new village of Ge Lao Wan in Xue town is gathered patterns of cities and towns. Through the relocation of immigrant time, reason and living status, such as the two patterns involved are explained as follow:

Interactive mode: village mines is because the resident living area contains high quality coal resources, they need to build the relevant facilities or residential area due to long-term coal mining subsidence and have given the housing cracks, organization, coal mine in government and the masses and under the principle of combining voluntary migration patterns. In this mode, the government guide encourage villagers to legitimate income, capital, technology and labor capital and coal enterprises to carry out a variety of forms and cooperation, closely linked to the enterprise development and the masses' income, promote village common development, realize enterprise profit, farmers become rich, the mining area and harmonious model.

Town gathered mode: This is leaded by government, self-raised self-built, appropriate guidance, the wishes of the masses support, under the principle of the remote village, village shack, traffic inconvenience, living conditions is restricted by a lot of natural villages moved into the town of township or county area, and other administrative villages in the region formed on agglomeration, thus produce accumulative effect model. For example, Jin Jia Zhuang rural village of hemp tail groove moved to the center of the villages and towns economic zone, and Jin Jia Zhuang village form in geographic agglomeration. 


\section{Liulin, Poverty Alleviation and Immigration Practice Mode Analysis of the Effect}

Immigration will readjust the production factors in poverty-stricken areas for poverty alleviation and reconfigure the population of the local resources, but also change people's production and life style and update ideas. In this article, through access to the reason of the four village immigrants, immigrants time, money, and the actual situation of life after immigration, and analyzes the general characteristics of four village immigration, the Liulin, poverty alleviation and the practical mode of immigrants is divided into two categories: one is the village ore interaction effect analysis of immigration, Chen Jia Wan town Guo Jia Shan village and the town after Hou Yuan Zhuang village; Another kind is town gathered mode effect analysis of immigration, namely Jin Jia Zhuang town Ma Wei Gou village and new village of Ge Lao Wan in Xue town. From the economy, people's livelihood, ecological and social four aspects analyzes the Grahame immigration practice patterns of positive and negative effects.

\subsection{To Zhuang Village Ore Interaction Effect Analysis in Hou Yuan Zhuang Village as an Example}

Belong to the Qian Yuan Zhuang village after administrative villages in the village, the village started in 2008 immigration project, completed by the end of 2009, to all residents relocation in 2010, the village build a total of 76 suites, including 2 sets of seat for public facilities, with 74 sets of residents housing. It is 200 meter from new village to their old home, and it is 10 kilometer from the county seat. Village relocation household has 86 households, more than 380 people, after the relocation former land has carried on the comprehensive level, has no population live above the residents of the rest did not move immigrants, some rent a house, some people who has good economic conditions already bought housing. Funds have coal subsidies 30,000 yuan per person, when in the open comb-shaped according to house housing quality stand or fall of funding. Housing types from high to low is divided into four grades, the corresponding price from high to low, the four grades, namely the bungalow 450 yuan per square kilometer, brick houses 400 yuan per square kilometer, the combination of adobe houses 250 yuan per square kilometer, pure kiln 150 yuan square kilometer. Price changes along with the height of building quality, building high quality good price also corresponding; On the contrary, poor building quality status is low in price.

\subsubsection{Economic Effect}

The village land slope, and slope is greater than 30 degrees; the summer rainfall concentrated period increased soil erosion, soil more barren, not conducive to the growth of crops. In addition, in recent years, due to the changing climate, greatly reduces the yield of crops, so that people rely on farming to sustain life. After immigration $80 \%$ of the residents, to the coal mine enterprise work, a stable income, improve the standard of living. The shortage is the relocation of the village is still no school, the village is currently being built in the school, but now parents want to send their children to the city a better quality of teaching to go to school, even if the repair school, also very few 
people are willing to go back to school in the village, it will cause a waste of resources. The relocation of the village did not realize the urban agglomeration, which is not conducive to economic development.

\subsubsection{Livelihood Effect}

People's livelihood is the vital interests of the people. The living conditions of the residents relocation after the village was improved but there are also some negative effects. During the visit to the residents living water sources on underground water supply, due to emissions of long-term local coal mine waste water and gas, solid waste and other pollutants, after precipitation, the surface runoff and infiltration caused serious pollution to the water. The villagers from wells up the water taste too salty, not drinking, so the villagers can only go before the Qian Yuan Zhuang village to buy water, while the village from the village before the Qian Yuan Zhuang 2.5 kilometer away, which caused great inconvenience to the residents of water. In addition, distance after removal of the location of 100 meter underground vent Hing mine, ventilation equipment constantly need to transport by air to the underground, noise generated by the equipment operation has seriously affected the lives of local villagers.

\subsubsection{Ecological Effect}

After the relocation of the village, in under the guidance of government policy, for the most of farm land implement returning farmland to forest, this is conducive to water conservation, climate regulation, improve the local ecological environment, effective control of soil erosion. In the long term to ensure a virtuous cycle of local agricultural ecological environment, laid the foundation for the realization of the harmonious development of man and nature. But in interviews with several villagers have individual villagers reflect, emissions from coal mine sewage into the farmland in and caused the trees, crops died, exacerbated by soil pollution.

\subsubsection{Social Effects}

The immigrant village will be scattered living in mountainous masses centralized resettlement to the village, which facilitate the mutual exchanges and learning between residents. Is to change the old ideas of the masses of immigrants, for the masses to further increase our knowledge, renew the idea, improve quality of life, created favorable conditions.

In general, the village of immigrants, although there are some negative effects, but immigrant residents living conditions and income level improved. That will provide economic base for the construction of ecological civilization in rural areas.

\subsection{Effect Analysis of Urban Agglomeration Pattern: A Case Study of the Ge Lao Wan Village in the Town of Xue}

The village of Ge Lao Wan immigration project started in the spring of 2007 and completed to the end of 2007. The villagers in 2008 gradually relocated to stay. Old village 1 kilometer from the village, away from the town 15 kilometer, a total of relocation 86 people of 15 families, which has 1 households because of the old village to do tofu con- 
venient no relocation. Village has built 15 suites; each suite covers an area of 135 square meters. The village covers an area of 3750 square meter. The price is 80,000 yuan of each house, the government subsidies for 2000 yuan per person. Figure 1 for comparison of the housing before and after the Ge Lao Wan village in the town of XUE Immigration:

\subsubsection{Economic Effect}

The village of Ge Lao Wan from the mountains closed behind the relocation to the traffic of Da Cheng. Tha facilitate the residents work outside the home and facilitate the travel of residents to buy daily necessities. It will not only improve the income levels of residents, but also to expand the consumption and to promote the Liulin County economic development.

\subsubsection{Livelihood Effect}

From Figure 1 it can be clearly seen that after the relocation of the residents living conditions have been significantly improved. The old villages have no water, electricity and school. After the relocation and the road opposite the village shared utilities and other infrastructure, which improve the living conditions of residents. The village is across the highway after Dacheng village natural village, this will convenient village grassroots cadres and villagers. The villagers can only to distance 2.5 kilometer away Xue village to buy water because the tap water pipe have not yet been repaired, which make the residents living water caused great inconvenience.

\subsubsection{Ecological Effect}

The poor people under the pressure of survival can only continue to the vegetation resources in neighboring finite were reclamation and deforestation before the relocation of the village because of the long living in remote mountainous areas. Resulting in the ecological environment more fragile of poor areas and the soil erosion is more serious. From a long-term guarantee the sound development of the agricultural and ecological environment and lay a good foundation for the realization of the human and the natural harmonious development and the construction of ecological civilization society through the implementation of returning farmland to forest and grassland, vegetation restoration, soil and water conservation, regulating climate, effective control of soil erosion

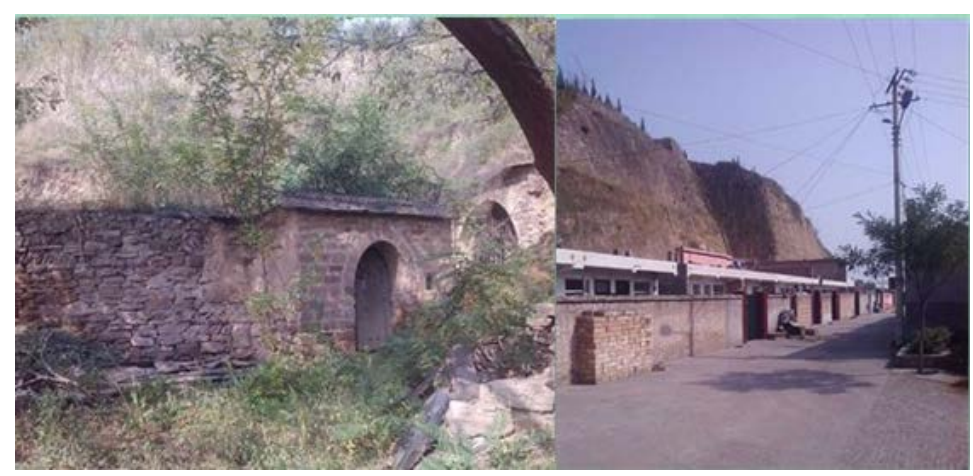

Figure 1. The housing landscape contrast of the old village and new village. 
and alleviate the ecological environment In helping immigrants to move out after the mountain.

\subsubsection{Social Effects}

The village closed terrain mountain relocation to the edge of the road. It is the village of Da Cheng on the opposite side of the road. This will promote the exchange between the masses of immigrants and the local residents learn from each other. Especially, that will update the concept of the masses, improve the quality and create favorable conditions for masses of immigrants from the ecological environment of the closed and backward to move out to broaden the production life and social environment.

\section{Conclusion and Prospect}

\subsection{Conclusion}

The necessity of immigrants in Liulin County situation and poverty alleviation, immigration practice mode and its actual effect were analyzed and found in Liulin County immigration, although there are some shortcomings, but immigrants could improve the living conditions of residents significantly, improve traffic conditions, to promote economic development, to further improve the people's livelihood and provide a good economic foundation for building a harmonious society and building a new countryside. Because of lack of the experience and exercise in the field research, lack of the ability of analyzing the investigation data, the deficiency is not in Liulin County by roads and railway construction projects of immigrant village visited only on the relocation time, reason, place, villagers on immigration attitudes and other aspects of general understanding, did not understand that the immigrant village in the township and a detailed understanding of the situation of the body of immigrants of Liu Lin County on the whole.

\subsection{Prospect}

The relocation is related to the survival of the people and the local immigration and social harmony and stability of the Huimin project. It will cause the waste of resources or regional facilities lag, residents living conditions are not met and will soon lead to new social problems if there is no long-term and reasonable planning. So I hope the Liulin County Government can adopt the following suggestions in the relocation of the future. First, combine the village mine interaction model with towns combination mode, then make the resources effective use and promote the rapid of economic development; Secondly, increase the investment of relocation; Thirdly, focus on the development of the economy and improve people's livelihood; Finally, increase the construction of ecological civilization investment, to achieve the steady development of resettlement work (Zhang Xiaohong, Zhang Jiancheng, \& Yang Manhong, 2008).

\section{Fund}

National Social Science Fund Project "Large-scale Ecological Migration Sustainable 
Development in Poor Areas" (12BJL076), Shanxi Province Philosophy and Social Science Project "Poverty Migration Patterns study in Shanxi".

\section{References}

Li Jiulin, Li Ruzhi, \& Liu Tingkui. 李九林, 李茹芝, 刘廷奎. (1995). Liulin County 柳林县志. Chinese Tide Press 中国海潮出版社, 40-123.

Li Wangming, \& Jin Dengyang. 李王鸣, 金登杨. (2008). Analysis and Demonstration of Resettlement Model of Poverty Alleviation-Taking Ruian City of Zhejiang Province as an Example 移民安置模式分析与实证一以浙江省瑞安市为例. 经济地理, p. 205.

Yang Guolin, \& Luo Qiangqiang. 杨国林, 罗强强. (2009). Study on the Experience and Effect of Poverty Alleviation in Ningxia 宁夏移民扶贫开发的经验和效果. Agricultural Modernization Research 农业现代化研究, 575-578.

Zhang Xiaohong, Zhang Jiancheng, \& Yang Manhong. 张晓红, 张建成, 杨满红. (2008). On the Promotion of Our Province on the Migration of Shanxi 关于推进我省扶贫移民工作的思考. Shanxi 山西农经, 34-38.

Submit or recommend next manuscript to SCIRP and we will provide best service for you:

Accepting pre-submission inquiries through Email, Facebook, LinkedIn, Twitter, etc. A wide selection of journals (inclusive of 9 subjects, more than 200 journals)

Providing 24-hour high-quality service

User-friendly online submission system

Fair and swift peer-review system

Efficient typesetting and proofreading procedure

Display of the result of downloads and visits, as well as the number of cited articles

Maximum dissemination of your research work

Submit your manuscript at: http://papersubmission.scirp.org/

Or contact.hnstd@scirp.org 